\title{
Emergence of Multidrug-resistance Bacteria Isolated of Drinking Water, Groundwater and Hospital Wastewater in Southern Benin: Antibiotic Resistance Profile and Resistomes Determination
}

\section{Hornel Koudokpon}

University of Abomey-Calavi: Universite d'Abomey-Calavi

Victorien Dougnon ( $\nabla$ victorien.dougnon@gmail.com )

University of Abomey-Calavi: Universite d'Abomey-Calavi https://orcid.org/0000-0001-9047-7299

Christelle Lougbegnon

University of Abomey-Calavi: Universite d'Abomey-Calavi

\section{Alidehou Jerrold Agbankpe}

University of Abomey-Calavi: Universite d'Abomey-Calavi https://orcid.org/0000-0002-0547-7065

Gérardine Avodagbe

University of Abomey-Calavi: Universite d'Abomey-Calavi

\section{Souad Saidou}

University of Abomey-Calavi: Universite d'Abomey-Calavi

Honoré Bankole

University of Abomey-Calavi: Universite d'Abomey-Calavi

\section{Lamine Baba-Moussa}

University of Abomey-Calavi: Universite d'Abomey-Calavi

\section{Research}

Keywords: Drinking water, hospital wastewater, groundwater, multidrug-resistance bacteria, resistome determination, southern Benin

Posted Date: March 9th, 2021

DOI: https://doi.org/10.21203/rs.3.rs-245521/v1

License: @ (i) This work is licensed under a Creative Commons Attribution 4.0 International License. Read Full License 


\section{Abstract}

Background: The environment plays an important role in the dissemination of multidrug resistant bacteria, especially through the aquatic ecosystem, which is made up of liquid hospital effluents, rivers, but also spring water and drinking water. This study aims to determinate resistomes in some aquatic matrices in southern Benin.

Methods: These samples were filtered through a membrane $0.22 \mu \mathrm{m}$ thick. After filtration, the membrane was deposited on Muëller Hinton agar. Then the colonies resulting from this subculture were subjected to a microbiological examination by the conventional method. The antibiotic sensitivity test was carried out by the Kirby Bauer method according to the recommendations of the French Society of Microbiology. Resistance genes were looked for by standard PCR and the PCR products were used for agarose gel electrophoresis.

Results: Of the 222 water samples collected, 265 bacterial strains were isolated, the majority of which were strains of Coagulase Negative Staphylococcus (CNS) with $37.74 \%$ ( $n=100$ ), followed by strains of Klebsiella pneumoniae (21.89\%; $\mathrm{n}=58)$, Escherichia coli $(10.57 \% ; \mathrm{n}=28)$. All isolated gram-negative bacilli strains are multidrug resistant with resistance of all strains to amoxicillin, ampicillin and amoxicillin + clavulanic acid. Of the 15 resistance genes sought in the genome of Gram-negative bacilli strains, only 8 were detected, namely the TEM, SHV, CTX-M15, VIM, NDM, SUL1, SUL2 and AADA genes. Strong resistance of CNS strains to amoxicillin, oxacillin and cefoxitin was observed. The Mec A gene was detected in all CNS strains. While the Van A and Van $B$ genes were only detected in strains isolated from drinking water in sachets collected from producers and street sellers.

Conclusion: These results show the dissemination of resistance genes in the aquatic ecosystem of Benin and once again confirms the urgency of a global fight against antimicrobial resistance.

\section{Background}

Antibiotic resistance is a major problem of public health in the world. This phenomenon affects all industrialized and non-industrialized countries [1]. The major causes of this phenomenon of antibiotic resistance are the inappropriate and fanciful use of antibiotics in human health [2], the joint use of antibiotics in animal health, agriculture and human health [1-3]. In addition to these causes, the role of the environment in the spread of resistance to antibiotics has been increasingly questioned in recent years [4]. Numerous studies have shown the role of the environment as a source or reservoir of resistant bacteria, antibiotic resistance genes and antibiotic residues that contribute to the selection of multidrug resistant germs $[5,6]$. Many matrices have been targeted as a source of dissemination of multidrug resistant bacteria in the environment and to humans, but water resources constitute an important source of dissemination of these multidrug resistant bacteria [7].

Effluent hospital liquid, passing by piping waters and drinking water have been implicated as a vehicle for the spread of multidrug-resistant bacteria [8]. Integrated management of water resources would reduce the spread of pathogens both in hospitals and in the community [9]. However, the implementation of these management policies for both wastewater and drinking water is still precarious in developing countries like Benin. 
Indeed, numerous studies showed the presence of multidrug resistant bacteria in the environment in Benin [1014]. The vast majority of hospitals do not have a treatment and purification system for hospital liquid effluents which are in the majority of cases discharged into the environment and into the great lakes. The drinking water is produced without any hygienic quality control and sold in the streets, sometimes under the sun. However, it is well known that at certain temperatures microorganisms can multiply in drinking water. These are all problems that led to the implementation of this study, which aims to identify the ecologies of multidrug resistant bacteria in liquid effluents and in drinking water in the knowledge of Benin.

\section{Material And Methods}

\section{Zone and Period of Study}

The study was carried out in southern Benin in the municipalities of Cotonou, Abomey-Calavi and Seme-Kpodji. It was carried out during the period from July to September 2020. In the municipalities of Cotonou and AbomeyCalavi, samples of drinking water in sachets were taken both from producers and from street sellers. As for the samples of wastewater (hospital environment) and groundwater (well water) intended for the consumption of the populations, they were taken in the commune of Seme-Kpodji.

\section{Sample collection}

Four different brands of drinking water in sachets (33 $\mathrm{ml}$ of water / sachet) were selected and their producers were identified in the communes of Cotonou and Abomey-Calavi. 30 samples of this water were taken from each of the four producers. Randomly, two street sellers of each brand of drinking water were chosen and 10 water samples were purchased from them in the communes of Cotonou and Abomey-Calavi. 10 samples of wastewater were then taken in the Seme-Krake Health Center in the commune of Seme-Kpodji. 6 wells were randomly selected from the houses surrounding the Health Center and 2 groundwater samples were taken per well. Thus, a total of 172 water samples were taken as part of this study (Table 1). $1000 \mathrm{ml}$ of each of the hospital wastewater and groundwater samples were collected in a sterilized vial at each site. The collected samples were transported directly to the laboratory in a cooler containing cold accumulators. The samples were handled on the same day. If necessary, they were stored at $+4{ }^{\circ} \mathrm{C}$ while awaiting their handling.

\section{Bacteriological identification}

Once in the laboratory, each sample was filtered twice using a filtration pump through a $0.22 \mu \mathrm{m}$ membrane. The volume of each filtered sample was $300 \mathrm{ml}(2 \times 150 \mathrm{ml})$. After filtration, the two membranes obtained from each sample were removed and placed respectively on Manitol Salt agar plates and on Eosine Methylene Blue agar. These plates were incubated at $37^{\circ} \mathrm{C}$ for $18 \mathrm{~h}$. The Gram stain was carried out on the colonies obtained after 18 $\mathrm{h}$. Then these colonies were seeded on Mueller Hinton agar plates and incubated for $18 \mathrm{~h}$ at $37^{\circ} \mathrm{C}$ to obtain young pure colonies. Each colony obtained was used for identification of bacterial species by the classical method of microbiology based on Gram control and biochemical characteristics (catalase, oxidase, seeding of the API 20 E gallery (for only Gram-negative bacilli), free staphylocoagulase and Dnase tests (for only Grampositive cocci).

\section{Antibiotic susceptibility test}


The antibiotic susceptibility test of the isolated strains was carried out by the method of Kirby Bauer which consists of the diffusion of the discs of antibiotics on the Mueller Hinton II agar according to the recommendations of the French Society of Microbiology [16]. the antibiotic disc panel used for Gram positive cocci is composed of AMX: Amoxicillin $(25 \mu \mathrm{g})$; OXA: Oxacillin $(5 \mu \mathrm{g})$; VA: Vancomycin $(30 \mu \mathrm{g})$; FOX: Cefoxitin $(30 \mu \mathrm{g})$; TOB: Tobramycin $(10 \mu \mathrm{g})$; GEN: Gentamycin $(15 \mu \mathrm{g})$; FO: Fosfomycin $(200 \mu \mathrm{g})$; DA: Clindamycin $(2 \mu \mathrm{g})$; E: Erythromycin $(15 \mu \mathrm{g})$ and for Gram negative bacilli the panel is composed of AMX: Amoxicillin (25 $\mu \mathrm{g})$; AMP: Ampicillin $(25 \mu \mathrm{g})$; AMC: Amoxicillin + Clavulanic acid $(30 \mu \mathrm{g})$; IMP: Imipenem $(15 \mu \mathrm{g})$, CRO: Ceftriaxone $(30 \mu \mathrm{g})$, NA: Nalidixic Acid (30 $\mu \mathrm{g})$; AK: Amikacin $(30 \mu \mathrm{g})$; GEN: Gentamycin $(15 \mu \mathrm{g})$.

\section{Search for resistance and virulence genes}

The search for resistance genes was carried out by standard PCR. Each purified colony was used for DNA extraction in accordance with the manufacturer's instructions (ZymoBiomics DNA/RNA Kit; Zymo Research, Californie, United Nation). the resistance genes sought are: bla TEM, bla SHV, bla CTX-M15, qnr A, IMP, VIM, NDM, KPC, GES, OXA-48, OXA-28, DHA, AADA, mcr-1, sul 1, sul 2, mec A, Van A, Van B. The list of primers used as well as the PCR conditions used are shown in table 2. The PCR mix is prepared according to the supplier's instructions according to the composition below. Master Mix 12,5 $\mu$; $\mathrm{H}_{2} \mathrm{O}$; DNA free 7,5 $\mathrm{ll}$; Each primer $1 \mu \mathrm{l}$; DNA, $3 \mu \mathrm{l}$ (One Taq, Biolabs New England, Evry, France).

\section{Statistical analysis}

The data were entered into an excel spreadsheet and analyzed with SPSS software. The graphics were made using Graphpad Prism 7 software.

\section{Results}

\section{Different bacterial strains identified}

Of the 222 water samples collected, 265 bacterial strains were isolated, the majority of which were strains of Coagulase Negative Staphylococcus (CNS) with 37.74\% $(\mathrm{n}=100)$, followed by strains of Klebsiella pneumoniae (21.89\%; $\mathrm{n}=58)$, Escherichia coli $(10.57 \% ; \mathrm{n}=28)$, Aeromonas spp. $(06.42 \% ; \mathrm{n}=17)$ and Proteus mirabilis (06.04\%; $\mathrm{n}=16)$. Regarding hospital wastewater samples, the most isolated bacterial species were Klebsiella pneumoniae (28\%), Aeromonas spp. (24\%) and Escherichia coli (24\%). A predominance of strains of Aeromonas spp. (33.33\%) and CNS (30.30\%) was observed in the groundwater samples. As for the samples of drinking water in sachets taken from producers, a predominance was observed for strains of CNS (45.80\%), followed by strains of K. pneumoniae (26.72\%) and E. coli (13.74\%). The same remark was made for drinking water samples taken from street vendors, a predominance of CNS strains (31.58\%), followed by Proteus mirabilis (21.05\%) and K. pneumoniae (13.16\%) strains (Table 3).

\section{Resistance of Gram-negative bacilli strains to the antibiotics used}

The test of antibiotic resistance showed that all isolated gram-negative bacilli strains are multidrug resistant with resistance of almost all strains to amoxicillin, ampicillin and amoxicillin + clavulanic acid. Moderate resistance was noted to ceftriaxone and very low resistance to imipenem (Figure 1). However, we noted that all strains of K. pneumoniae isolated from groundwater were sensitive to amikacin, nalidixic acid and gentamicin. 
While the strains of Aeromonas spp. isolated from the same samples were only sensitive to amikacin. As for the $P$. aeruginosa strains isolated from the same samples, they were sensitive to imipenem, amikacin and gentamicin (Figure 1A). The strains isolated from the samples of hospital wastewater showed very strong resistance to the antibiotics used. Thus, the strains of $K$. pneumoniae showed strong resistance to amoxicillin (100\%) and ampicillin (100\%) and moderate resistance to omoxicillin + clavulanic acid (50\%). All strains of Aeromonas spp. showed complete resistance to amoxicillin, ampicillin, amoxicillin + clavulanic acid and nalidixic acid and $50 \%$ resistance to ceftriaxone, imipenem, amikacin and gentamicin. As for the $E$. coli strains, they were all resistant to amoxicillin, ampicillin, amoxicillin + clavulanic acid and ceftriaxone (Figure 1B). The resistance of strains isolated from drinking water in sachets collected from producers showed that all strains of Shigella spp. isolated were resistant to all antibiotics tested except amikacin. Strains of Enterobacter spp. isolated from the same samples also showed complete resistance to amoxicillin, ampicillin, amoxicillin + clavulanic acid, ceftriaxone and gentamicin. Strains of $K$. pneumoniae, on the other hand, showed strong resistance to amoxicillin (100\%), ampicillin (100\%) and amoxicillin + clavulanic acid (60\%), and low resistance to ceftriaxone (40\%) and imipenem (20\%) (Figure 1C). All the strains isolated from drinking water in sachets collected from street vendors showed total resistance to amoxicillin, ampicillin and amoxicillin + clavulanic acid, except for the strains of Enterobacter spp. which showed resistance of $66.67 \%$ to amoxicillin + clavulanic acid and strains of Serratia spp which showed low resistance of $33.33 \%$ to amoxicillin, ampicillin and amoxicillin + clavulanic acid (Figure 1D).

\section{Resistance genes detected in Gram-negative bacilli}

Of the 15 resistance genes sought in the genome of Gram-negative bacilli strains, only 8 were detected, namely the TEM, SHV, CTX-M15, VIM, NDM, SUL1, SUL2 and AADA genes. Thus, in all 23 strains of Gram-negative bacilli, the SHV gene was detected with a frequency of $56.52 \%(n=13)$, followed by the SUL2 gene $(52.17 \% ; n=12)$, AADA gene (39.13\%; $n=9)$ and VIM gene (13.04\%; $n=3)$. The SHV, CTX-M15, VIM, SUL2 and AADA genes were detected at the same frequency of $15.79 \%(n=3)$ on all 19 strains of Gram-negative bacteria isolated from hospital wastewater. Among the 71 Gram negative bacilli strains isolated from sachet drinking water collected from producers, the most detected gene is SUL2 with a frequency of $26.76 \%(n=19)$, followed by the AADA gene (18.31 \%; $n=13)$, SHV gene (14.08 \%; $n=10)$, VIM gene (08.45 \%; $n=6)$, NDM and TEM genes $(04.23 \% ; n=$ $3)$. As for the strains $(n=76)$ isolated from sachet drinking water collected from street vendors, the most detected gene was SHV (32.69 \%; $n=17)$, followed by the SUL1 gene $(28.85 \% ; n=15)$, SUL2 gene $(23.08 \%, n=$ 12), TEM gene (19.23\%; $n=10)$, AADA gene (9.62 \%; $n=5)$, CTX-M15 (5, $77 \% ; n=3)$ and NDM gene (3.85 \%; $n=$ 2) (Figure 2).

Table 4 shows the association of resistance profiles and resistance genes of the bacterial strains (Gram-negative bacilli) isolated according to the different types of samples. Thus, out of the 58 strains of K. pneumoniae isolated in this study, 4 resistance profiles were established. These 4 profiles are associated with 5 resistance genes (SUL1, SUL2, AADA, SHV and VIM). Of the 28 strains of $E$. coli isolated in our study, 3 resistance profiles were established and then associated differently with 3 resistance genes (CTX-M15, TEM and SHV). Only one resistance profile was not associated with any resistance gene. This strain was isolated from drinking water in sachets collected from producers. 5 resistance profiles were established after the susceptibility test of the strains of Aeromonas spp. antibiotics. These 5 profiles were associated with 4 resistance genes (SHV, VIM, AADA and SUL2). However, 3 strains of Aeromonas spp. isolated from hospital wastewater and having the same resistance profile were not associated with any resistance gene. Regarding the $P$. aeruginosa strains isolated in this study, 3 
resistance profiles were established with an association of 5 resistance genes (TEM, SHV, SUL1, SUL2, AADA) (Table 4).

\section{Resistance of Gram-positive cocci strains to the antibiotics used}

All Gram-positive cocci strains isolated in this study are all coagulase-negative staphylococcus (CNS). A total of 100 strains of CNS were isolated (Table 3). The susceptibility test of the CNS strains to the antibiotics used showed that all the CNS strains isolated from hospital wastewater were resistant to all antibiotics tested except fosfomycin and erythromicin. Strains isolated from groundwater showed high resistance to amoxicillin (100\%), oxacillin (100\%) and cefoxitin (80\%) and low resistance to vancomycin (40\%), fosfomycin (20\%) and clindamycin (20\%). As for the strains isolated from drinking water in sachets collected from producers, the highest resistance is to amoxicillin (72.73\%), oxacillin $(72.73 \%)$ and cefoxitin $(63,64 \%)$. While, the resistance of strains from drinking water in sachets collected from street vendors is much higher to amoxicillin (72.73\%), oxacillin (54.55\%), and fosfomycin (54.55\%) (Figure 3).

\section{Resistance genes detected in coagulase-negative staphylococcus (CNS) strains}

Three resistance genes ( Mec A, Van A and Van B) were detected in the genome of the CNS strains isolated during this study. The Mec A gene was detected in all strains isolated from groundwater (100\%) and hospital wastewater (100\%). This same gene was detected at $71.67 \%$ and at $41.67 \%$ in strains isolated respectively from drinking water in sachets collected from producers and street vendors. As for the Van A gene, it was detected in strains isolated from drinking water in sachets collected from producers and street vendors with frequencies of $33.33 \%$ and $8.33 \%$ respectively. Whereas, the Van B gene was detected only in the strains isolated from drinking water in sachets collected from producers with a frequency of $33.33 \%$ (Figure 4).

Out of the 100 CNS strains, we were able to establish with the results of the susceptibility test of these strains to the antibiotics used, 17 different resistance profiles. These resistance profiles were associated with the resistance genes Mec A, Van A and Van B. All this according to the types of samples analyzed (Table 5).

\section{Discussion}

Public health problem around the world. The presented study carried out on drinking water, wastewater and groundwater around the hospital shows the presence of bacteria such as Aeromonas spp., Klebsiella pneumoniae, Pseudomonas aeruginosa, Escherichia coli, Proteus mirabilis.

The presence of Aeromonas spp. in aquatic ecosystems was noted by numerous studies [25]. For the authors [26,27], the presence of this genus in the aquatic environment is natural because they are ubiquitous and especially present in the soil, on plants and in water. However, this genus can be involved in human and animal infections, especially in the contamination of fish [28]. The absence of this bacterial genus in drinking water is contrary to numerous studies which have isolated this genus in many drinking waters sources [29-31]. The absence of this kind in our drinking water samples is due to the preliminary treatment with molecules based on alum before marketing. These molecules therefore have an action on the genus Aeromonas which is known for its involvement in human infections by many toxins that it produces [32]. The presence of this kind in hospital wastewater were also documented by authors [33]. Bofill-Mas et al. [34] showed in their studies that 
bacteria of the genus Aeromonas can be found in groundwater and municipal pipes near hospitals by irrigation of hospital wastewater.

The presence of other bacteria such as Enterobacter spp., Klebsiella pneumoniae, Proteus mirabilis in our samples corroborates the results obtained by Olaoye and Oniludé [35] who carried out their studies in the southwest of Nigeria, part of the border with our study area. Indeed, our study area shares a strong practice with the study area of the latter. This shows that the problem of contamination of drinking water in sachets has not been resolved over time. On the contrary, the practice of selling these waters without control continues and spreads from day to day.

In our study, we noted a weak diffusion of bacteria between the wastewater and the surrounding groundwater. This shows the efficiency of the water treatment system in the health center. This should serve as a model for other health centers which generally do not provide for any treatment strategy for these hospital liquid effluents. These observations join those of Buelow et al. [36] who have shown the limitation of the influence of liquid hospital effluents on the resistome and on the microbiome. The strong presence of coagulase negative staphylococcus in our study may reflect poor hygiene in the packaging of bags consumption waters and the risk of cross-transmission through the hands in hospital environments mismanagement of hospital wastewater. It is well known that the coagulase negative staphylococci, commensal of the water are strongly involved in the cross transmission of the germs by the hand in both community and hospital settings [37].

The study of resistance to the antibiotic showed the presence of many resistance genes to beta-lactams whose resistance genes (TEM, SHV, CTX-M 15, NDM, VIM for Gram-negative bacilli and Mec A for Gram Positive Cocci), aminoglycosides (AADA) and glycopeptides (VAN A and Van B), sulfonamides (SUL 1 and SUL 2). Numerous studies have shown the presence of these resistance genes in bacteria isolated from water sources such as hospital wastewater and groundwater [8,38], drinking water $[30,39,40]$. The presence of certain multi-resistant bacteria and the absence of others in drinking water following the street sellers is the problem of distribution conditions of these drinking water bags. Indeed, this water generally in contact with heat (Sun or non-refrigerated collector contributes to the multiplication of certain multidrug resistant bacteria. This sector must therefore be supervised for better consumer safety [35]. Similarly, the results obtained show that surrounding groundwater have certain genes that do not come from the hospital wastewater. Indeed, the environment in general present a risk of spreading of multidrug resistant bacteria except those contributed by the wastewater. An effective fight against the has antimicrobial resistance is integrated a more comprehensive "One Health" approach includes the environment, animal health and human health [4].

\section{Conclusion}

These results, which took stock of the presence of multidrug resistant bacteria in sources of drinking water, hospital wastewater and groundwater, show the important role that the environment plays in the dissemination of multidrug resistant bacteria. and resistance genes. For an effective fight in this context, it will be necessary to adopt strategies taking into account all the fields concerned, which are animal health, human health and the environment.

\section{List Of Abbreviations}


HWW : Hospital WasteWater; GW : Groundwaters ; DWSP : Drinking Water IN Sachets-Producer ; DWSS: Drinking Water in Sachets-Street Seller; AMX: Amoxicillin ; AMP: Ampicillin ; AMC: Amoxicillin + Clavulanic acid ; IMP: Imipenem ; CRO: Ceftriaxone ; NA: Nalidixic Acid; AK: Amikacin ; GEN: Gentamycin ; R: Resistant; S: sensitive; CNS: coagulase negative staphylococcus; OXA: Oxacillin ; VA: Vancomycin ; FOX: Cefoxitin ; TOB: Tobramycin ; FO: Fosfomycin ; DA: Clindamycin ; E: Erythromycin

\section{Declarations}

\section{Ethics approval and consent to participate}

In this study we did not use samples of human origin. Our samples were water samples exclusively. However, we have also received the approval of drinking water producers and leads of households before the respective sampling of drinking water in sachets and groundwater (in wells). Likewise, the management of the Seme-Krake health center gave us the approval for the collection of hospital wastewater. This approval was notified to us by the notification letter ${ }^{\circ}$ 95/08 / MS / DDSOUE-PLA / CH-SEME-KRAKE / SAAE / DGAP / SGA of June 15, 2020.

\section{Consent for publication}

In our manuscript we did not include data from individuals. Because we did not handle a sample of human origin. Thus, we do not need to request consent for publication. However, all authors have consented for publication.

\section{Availability of data and material}

The datasets used and/or analyzed during the current study and material used are available from the corresponding author upon reasonable request.

\section{Competing interests}

The authors declare that they have no competing interests.

\section{Funding}

This work was not supported by any grants from funding agencies in the public or commercial sectors.

\section{Authors' contributions}

HK, VD, CL and AJA wrote the protocol. HK, VD, CL and GA processed the samples. VD and AJA did the statistical analyses and produce the graphs. HK, VD, AJA and SS wrote the draft of the manuscript. VD, HB and LB-M reviewed the manuscript. All authors read and approved the final version of the manuscript.

\section{Acknowledgements}

The authors thank the staff of the Seme-Krake Health Center involved in the study. The authors also thank Dr Esther DEGUENON for their technical support. They are grateful to the whole staff from the Research unit in Applied Microbiology and Pharmacology of natural substances (University of Abomey-Calavi, Benin). 


\section{References}

1. WHO. Résistance aux antimicrobiens. Organanisation Mondiale de la Santé. 2016 Aide-mémoi. http://www.who.int/mediacentre/factsheets/fs194/fr/. Accessed 22 Jul 2017.

2. Ouedraogo A, Pierre-Jean H, Banuls A, Ouédraogo R, Godreuil S. Emergence and spread of antibiotic resistance in West Africa: contributing factors and threat assessment. Médecine et Santé Tropicales. 2017, 27(2):147-154. doi: 10.1684/mst.2017.0678

3. WHO. Plan d'action mondial pour combattre la résistance aux antimicrobiens. Genève, Suisse. $2016 \mathrm{~b}$. http://apps.who.int/iris/bitstream/10665/249548/1/9789242509762-fre.pdf. Accessed 17 Oct 2017.

4. McEwen SA, Collignon PJ. Antimicrobial Resistance: a One Health Perspective. In: Antimicrobial Resistance in Bacteria from Livestock and Companion Animals. Microbiology Spectrum. 2018, 6(2): 521-47. doi: 10.1128/microbiolspec.ARBA-0009-2017.

5. Venter H, Henningsen ML, Begg SL. Antimicrobial resistance in healthcare, agriculture and the environment: The biochemistry behind the headlines. Essays in Biochemistry. 2017, 61:1-10. doi:10.1042/EBC20160053.

6. Oloso NO, Fagbo S, Garbati M, Olonitola SO, Awosanya EJ, Aworh MK, Adamu H, Odetokun IA, Fasina Antimicrobial resistance in food animals and the environment in Nigeria: A review. International Journal of Environmental Research and Public Health. 2018, 15(6):1284. doi: 10.3390/ijerph15061284.

7. Le Quesne WJF, Baker-Austin C, Verner-Jeffreys DW, Al-Sarawi HA, Balkhy H H, Lyons BP. Antimicrobial resistance in the Gulf Cooperation Council region: A proposed framework to assess threats, impacts and mitigation measures associated with AMR in the marine and aquatic environment. Environment International. 2018, 121 Pt 1:1003-10. doi:10.1016/j.envint.2018.06.030.

8. Smyth C, O'Flaherty A, Walsh F, Do TT. Antibiotic resistant and extended-spectrum $\beta$-lactamase producing faecal coliforms in wastewater treatment plant effluent. Environmental Pollution. 2020, 262:114244. doi:10.1016/j.envpol.2020.

9. Adeniji F. Global analysis of strategies to tackle antimicrobial resistance. International Journal of Pharmacy Practice. 2018, 26(1): 85-9. doi: 10.1111/ijpp.12365.

10. Ahoyo TA, Yehouenou PE, Baba-Moussa L, Attolou GA, Boco M, Dramane KL, Aminou T. Staphylococcus sciuri outbreak at tertiary hospital in Benin. Journal of Medical Microbiology \& Diagnosis. 2013, 2(3). DOI: 10.4172/2161-0703.1000126.

11. Ahouandjinou H, Baba-Moussa F, Sina H, Moussé W, Zull-Kifoul A, Akim S, Bonou J, Toukourou F, BabaMoussa L. Variability and antibiotics resistance of staphylococcus sp flora among the cattle carcasses. International Journal of Science, Environment and Technology. 2016a, 5(5) :3275-3288.

12. Ahouandjinou H, Baba-Moussa F, Gbaguidi B, Sina H, Adeoti Z-K, Moussé W, Pouadjeu-Wouansi S, Soumanou M, Toukourou F, Baba-Moussa L. Antibiorésistance et facteurs de Virulence des souches de Escherichia Coli Isolées des carcasses bovines du Bénin. European Scientific Journal. 2016b 12(33) : 493507.

13. Bankole H, Dougnon TV, Johnson CR, Ahoyo AT, De Souza M, Hounsa E, Hounmanou YMG, Baba-Moussa L. Bacteriological investigation of the infectious risks in a Semi-Public biomedical laboratory in Benin (West Africa). International Journal of Biology. 2016, 8(3): 45-57. DOI: 10.5539/ijb.v8n3p45.

14. Dougnon VT, Koudokpon H, Hounmanou YMG, Azonbakin S, Fabiyi K, Oussou A, Codjia I, Ahoyo A, BabaMoussa L, Bankole H. High Prevalence of Multidrug-Resistant Bacteria in the "Centre Hospitalier et 
Universitaire de la Mère et de l'Enfant Lagune (CHU-MEL)“ Reveals Implications of Poor Hygiene Practices in Healthcare. SN Comprehensive Clinical Medicine. 2019, 1, 1029-1037. doi:10.1007/s42399-019-00149-3.

15. The European Committee on Antimicrobial Susceptibility Testing (EUCAST). Breakpoint tables for interpretation of MICs and zone diameters. 2018; Version.2.0, http://www.eucast.org.

16. Memariani M, Najar-Peerayeh S, Taghi Salehi Z, Khalil S, Mostafavi S. Occurrence of SHV, TEM and CTX-M $\beta$-Lactamase Genes Among Enteropathogenic Escherichia coli Strains Isolated From Children With Diarrhea. Jundishapur Journal of Microbiology. 2015, 8(4): doi: 10.5812/jjm.8(4)2015.15620.

17. Li Y, Guo Q, Wang P, Zhu D, Ye X, Wu S, Wang M. Clonal dissemination of extensively drug-resistant Acinetobacter baumannii producing an OXA-23 $\beta$-lactamase at a teaching hospital in Shanghai, China. Journal of Microbiology, Immunology and Infect 2015, 48(1): 101-8. doi: 10.1016/j.jmii.2014.04.005.

18. Li Y, Liao H, Yao H. Prevalence of antibiotic resistance genes in air-conditioning systems in hospitals, farms, and residences. International Journal of Environmental Research and Public Health. 2019, 16, 683. doi:10.3390/ijerph16050683.

19. Taitt CR, Leski TA, Stockelman MG, Craft DW, Zurawski DV, Kirkup BC, Vora GJ. Antimicrobial resistance determinants in Acinetobacter baumannii isolates taken from military treatment facilities. Antimicrobial Agents Chemotherapy. 2014, 58(2): 767-781. doi: 10.1128/AAC.01897-13.

20. Seco BMS, Campos JC, da Costa Rocha DA, de Lima AV, de Oliveira FF, Lemo MEB, Sampaio SCF, Sampaio JLM. Improved blood culture workflow for faster identification of KPC-producing Enterobacterales. Brazilian Journal of Microbiology. 2018, 50:127-32. doi:10.1007/s42770-018-0037-y.

21. Monteiro J, Widen RH, Pignatari ACC, Kubasek C, Silbert S. Rapid detection of carbapenemase genes by multiplex real-time PCR. Journal of Antimicrobial Chemotherapy. 2012, 67(4): 906-9. doi:10.1093/jac/dkr563.

22. Yang Q, Rui Y. Two multiplex real-Time PCR assays to detect and differentiate Acinetobacter baumannii and non-baumannii, Acinetobacter Carrying blaNDM, blaOXA-23-Like, blaOXA-40-Like, blaOXA-51-Like, and blaOXA-58-Like Genes. PLoS One. 2016, 11(7), e0158958. doi: 10.1371/journal.pone.0158958.

23. Hassan W. Evaluation of Antimicrobial Resistance Dissemination in the Environment. Faculty of Biological Sciences, Quaid-i-Azam University; 2019.

24. Bittar F, Ouchenane Z, Smati F, Raoult D, Rolain JM. MALDI-TOF-MS for rapid detection of staphylococcal Panton-Valentine leukocidin. International Journal of Antimicrobial Agents. 2009, 34(5): ff10.1016/j.ijantimicag.2009.03.017ff.

25. Rusiñol M, Hundesa A, Cárdenas-Youngs Y, Fernández-Bravo A, Pérez-Cataluña A, Moreno-Mesonero L, Moreno Y, Calvo M, Alonso JL, Figueras MJ, Araujo R, Bofill-Mas S, Girones R. Microbiological contamination of conventional and reclaimed irrigation water: Evaluation and management measures. Science of The Total Environment. 2020, 710:136298. doi:10.1016/j.scitotenv.2019.

26. Kittinger C, Lipp M, Baumert R, Folli B, Koraimann G, Toplitsch D, Liebmann A, Grisold AJ, Farnleitner AH, Kirschner A, Zarfel G. Antibiotic resistance patterns of Pseudomonas isolated from the river Danube. Frontiers Microbiology. 2016, 7(586). doi:10.3389/fmicb.2016.00586.

27. Rivas Z. Aeromonas hydrophila In Amphibians: Harmless Bystander or Opportunistic Pathogen. Honor Undergrad Theses. 2016, https://stars.library.ucf.edu/honorstheses/13. Accessed 28 Nov 2020. 
28. Ma S, Sun C, Hulth A, Li J, Nilsson LE, Zhou Y, Börjesson S, Bi Z, Bi Z, Sun Q, Wang Y. Mobile colistin resistance gene mcr-5 in porcine Aeromonas hydrophila. Journal of Antimicrobial Chemotherapy. 2018, 73(7),1777-80. doi:10.1093/jac/dky110.

29. Robertson BK, Harden C, Selvaraju SB, Pradhan S, Yadav JS. Molecular Detection, Quantification, and Toxigenicity Profiling of Aeromonas in Source- and Drinking-Water. The Open Microbiology Journal. 2014, 8:32-9. doi:10.2174/1874285801408010032.

30. Vaz-Moreira I, Nunes OC, Manaia CM. Ubiquitous and persistent Proteobacteria and other Gram-negative bacteria in drinking water. Science of The Total Environment. 2017, 586:1141-9. doi:10.1016/j.scitotenv.2017.02.104.

31. Rather MA, Willayat MM, Wani SA, Hussain SA, Shah SA. Enterotoxin gene profile and molecular epidemiology of Aeromonas species from fish and diverse water sources. Journal of Applied Microbiology. 2019, 127:921-31. doi:10.1111/jam.14351.

32. Bhowmick UD, Bhattacharjee S. Bacteriological, clinical and virulence aspects of Aeromonas-associated diseases in humans. Polish Journal of Microbiology. 2018, 67:137-49. doi:10.21307/pjm-2018-020.

33. Sekizuka T, Inamine Y, Segawa T, Hashino M, Yatsu K, Kuroda M. Potential KPC-2 carbapenemase reservoir of environmental Aeromonas hydrophila and Aeromonas caviae isolates from the effluent of an urban wastewater treatment plant in Japan. Environmental Microbiology Reports. 2019, 11, 589-97. doi:10.1111/1758-2229.12772.

34. Bofill-Mas S, Girones R. Microbiological contamination of conventional and reclaimed irrigation water: Evaluation and management measures. Science of The Total Environment. 2020, 710, 136298. doi:10.1016/j.scitotenv.2019.

35. Olaoye OA, Onilude AA. Assessment of microbiological quality of sachet-packaged drinking water in Western Nigeria and its public health significance. Public Health. 2009, 123:729-34. doi:10.1016/j.puhe.2009.09.015.

36. Buelow E, Bayjanov JR, Majoor E, Willems RJL, Bonten MJM, Schmitt H, van Schaik Limited influence of hospital wastewater on the microbiome and resistome of wastewater in a community sewerage system. FEMS Microbiology Ecology. 2018, 94(7). doi:10.1093/femsec/fiy087.

37. Public Health Agency of Canada. Hand hygiene practices in healthcare settings . 2012. https://ipaccanada.org/photos/custom/OldSite/pdf/2013_PHAC_Hand Hygiene-FR.pdf. Accessed 28 Nov 2020.

38. Adelowo OO, Caucci S, Banjo OA, Nnanna OC, Awotipe EO, Peters FB, Fagade OE, Berendonk Extended Spectrum Beta-Lactamase (ESBL)-producing bacteria isolated from hospital wastewaters, rivers and aquaculture sources in Nigeria. Environmental Science and Pollution Research. 2018, 25(3) : 27442755. doi:10.1007/s11356-017-0686-7.

39. Lyimo B, Buza J, Subbiah M, Smith W, Call DR. Comparison of antibiotic resistant Escherichia coli obtained from drinking water sources in northern Tanzania: a cross-sectional study. BMC Microbiology. 2016, 16:110. doi:10.1186/s12866-016-0870-9.

40. Zhang K, Xin R, Zhao Z, Ma Y, Zhang Y, Niu Z. Antibiotic Resistance Genes in drinking water of China: Occurrence, distribution and influencing factors. Ecotoxicology and Environmental Safety, 2019, 188, 109837. doi:10.1016/j.ecoenv.2019.

\section{Tables}


Table 1. Distribution of samples according to their type and origin.

\begin{tabular}{|llll|}
\hline Municipalities & Type of sample & Number of samples & Total \\
\hline Cotonou & DWSP & $30 \times 2$ & 60 \\
\cline { 2 - 4 } & DWSS & $2 \times 2 \times 10$ & 40 \\
\hline Abomey-Calavi & DWSP & $30 \times 2$ & 60 \\
\cline { 2 - 4 } & DWSS & $2 \times 2 \times 10$ & 40 \\
\hline Seme-Kpodji & Hospital wastewater & 10 & 10 \\
\cline { 2 - 4 } & groundwater & $6 \times 2$ & 12 \\
\hline Total & 222 & & \\
\hline
\end{tabular}

DWSP: Drinking Water in Sachets - Producer; DWSS: Drinking Water in Sachets - Seller

Table 2. List of primers used 


\begin{tabular}{|c|c|c|c|c|}
\hline Gene & Primers & Sequence $5^{\prime}-3^{\prime}$ & Amplification Conditions & References \\
\hline \multirow[t]{2}{*}{ TEM } & TEM F & ATGAGTATTCAACATTTCCGC & \multirow{6}{*}{$\begin{array}{l}\text { ID: } 94{ }^{\circ} \mathrm{C} \text { for } 4 \text { min; } 32 \text { cycles (D: } \\
93^{\circ} \mathrm{C} \text { for } 30 \text { sec; } \mathrm{H}: 55^{\circ} \mathrm{C} \text { for } 30 \\
\text { sec; } \mathrm{E}: 72^{\circ} \mathrm{C} \text { for } 40 \mathrm{sec} \text { ); FE: } 72 \\
{ }^{\circ} \mathrm{C} \text { for } 4 \text { min }\end{array}$} & \multirow[t]{6}{*}{ [17] } \\
\hline & TEM R & CAATGCTTAATCAGTGAGG & & \\
\hline \multirow[t]{2}{*}{ SHV } & SHV F & AAGATCCACTATCGCCAGCAG & & \\
\hline & SHV R & ATTCAGTTCCGTTTCCCAGCGG & & \\
\hline \multirow[t]{2}{*}{$\begin{array}{l}\text { CTX- } \\
\text { M15 }\end{array}$} & $\begin{array}{l}\text { CTX- } \\
\text { M15 F }\end{array}$ & CACACGTGGAATTTAGGGACT & & \\
\hline & $\begin{array}{l}\text { CTX- } \\
\text { M15 R }\end{array}$ & GCCGTCTAAGGCGATAAACA & & \\
\hline \multirow[t]{2}{*}{ VIM } & VIM F & GCACTTCTCGCGGAGATTG & \multirow{14}{*}{$\begin{array}{l}\text { ID: } 95^{\circ} \mathrm{C} \text { for } 5 \text { min; } 35 \text { cycles (D: } \\
95^{\circ} \mathrm{C} \text { for } 30 \mathrm{sec} ; \mathrm{H}: 49^{\circ} \mathrm{C} \text { for } 45 \\
\text { sec; E: } 722^{\circ} \mathrm{C} \text { for } 30 \mathrm{sec} \text { ); FE: } 72 \\
{ }^{\circ} \mathrm{C} \text { for } 5 \text { min }\end{array}$} & \multirow[t]{2}{*}{ [18] } \\
\hline & VIM R & CGACGGTGATGCGTACGTT & & \\
\hline \multirow[t]{2}{*}{ GES } & GES F & GCAATGTGCTCAACGTTCAAG & & \multirow[t]{2}{*}{ [19] } \\
\hline & GES R & GTGCCTGAGTCAATTCTTTCAAAG & & \\
\hline \multirow[t]{2}{*}{ NDM } & NDM F & GGCCACACCAGTGACAATATCA & & \multirow[t]{2}{*}{ [20] } \\
\hline & NDM R & CAGGCAGCCACCAAAAGC & & \\
\hline \multirow[t]{2}{*}{ KPC } & KPC F & GCCGCCAATTTGTTGCTGAA & & \multirow[t]{2}{*}{ [21] } \\
\hline & KPC R & GCCGGTCGTGTTTCCCTTT & & \\
\hline \multirow[t]{2}{*}{$\begin{array}{l}\text { OXA } \\
48\end{array}$} & $\begin{array}{l}\text { OXA } 48 \\
\mathrm{~F}\end{array}$ & TGTTTTTGGTGGCATCGAT & & \multirow[t]{2}{*}{ [22] } \\
\hline & $\begin{array}{l}\text { OXA } 48 \\
\mathrm{R}\end{array}$ & GTAAMRATGCTTGGTTCGG & & \\
\hline \multirow[t]{2}{*}{$\begin{array}{l}\text { OXA- } \\
23\end{array}$} & $\begin{array}{l}\text { OXA-23 } \\
\mathrm{F}\end{array}$ & TTTACTTGCTATGTGGTTGCT & & \multirow[t]{2}{*}{ [23] } \\
\hline & $\begin{array}{l}\text { OXA-23 } \\
\mathrm{R}\end{array}$ & ATCACCTGATTATGTCCTTGA & & \\
\hline \multirow[t]{2}{*}{ DHA } & DHAF & TGGCCGCAGCAGAAAGA & & \multirow[t]{2}{*}{ [24] } \\
\hline & DHA R & CCGTTTTATGCACCCAGGAA & & \\
\hline \multirow[t]{2}{*}{$\begin{array}{l}\text { MCR- } \\
1\end{array}$} & $\begin{array}{l}\text { MCR-1 } \\
\text { F }\end{array}$ & CACATCGACGGCGTATTCTG & \multirow{4}{*}{$\begin{array}{l}\text { ID: } 95^{\circ} \mathrm{C} \text { for } 5 \text { min; } 45 \text { cycles (D: } \\
95^{\circ} \mathrm{C} \text { for } 30 \text { sec; } \mathrm{H}: 54{ }^{\circ} \mathrm{C} \text { for } 45 \\
\text { sec; } \mathrm{E}: 72{ }^{\circ} \mathrm{C} \text { for } 30 \mathrm{sec} \text { ); FE: } 72 \\
{ }^{\circ} \mathrm{C} \text { for } 5 \text { min }\end{array}$} & \multirow[t]{6}{*}{ [24] } \\
\hline & $\begin{array}{l}\text { MCR-1 } \\
\mathrm{R}\end{array}$ & CGATGTCGGTATGCTCGTTG & & \\
\hline \multirow[t]{2}{*}{ SUL1 } & SUL1 F & GCCGATGAGATCAGACGTATTG & & \\
\hline & SUL1 R & CGCATAGCGCTGGGTTTC & & \\
\hline \multirow[t]{2}{*}{ SUL2 } & SUL2 F & TCATCTGCCAAACTCGTCGTTA & \multirow{2}{*}{$\begin{array}{l}\text { ID: } 95^{\circ} \mathrm{C} \text { for } 10 \mathrm{~min} ; 40 \text { cycles } \\
\left(\mathrm{D}: 95^{\circ} \mathrm{C} \text { for } 30 \mathrm{sec} ; \mathrm{H}: 51^{\circ} \mathrm{C} \text { for }\right. \\
\left.30 \mathrm{sec} \text {; } 72^{\circ} \mathrm{C} \text { for } 15 \mathrm{sec}\right) ; \mathrm{FE}: \\
72{ }^{\circ} \mathrm{C} \text { for } 5 \mathrm{~min}\end{array}$} & \\
\hline & SUL2 R & GTCAAAGAACGCCGCAATGT & & \\
\hline
\end{tabular}


AADA AADAF TGTACGGCTCCGCAGTG

AADA CACGGAATGATGTCGTCGTG

$\mathrm{R}$

MEC MEC A GTTAGATTGGGATCATAGCGTCATT ID: $94{ }^{\circ} \mathrm{C}$ for 4 min; 30 cycles (D:

A F $\quad 94^{\circ} \mathrm{C}$ for $1 \mathrm{~min} ; \mathrm{H}: 50{ }^{\circ} \mathrm{C}$ for 1

MEC a tgCCTAATCTCATATgtgtTCCTgtat ${ }^{\circ} \mathrm{C}$ for 5 min

$\mathrm{R}$

VAN VAN A GGGCTGTGAGGTCGGTTG

[24]

A $F$

VAN A TTCAGTACAATGCGGCCGTTA
$\mathrm{R}$

VAN VAN B TTGTCGGCGAAGTGGATCA

B F

VAN B AGCCTTTTTCCGGCTCGTT

$\mathrm{R}$

ID: Initial Denaturation; D: Denaturation; H: Hybridization; E: Elongation; EF: Final Elongation

Table 3. Distribution of bacterial species isolated from water samples

\begin{tabular}{|c|c|c|c|c|c|c|c|c|c|c|}
\hline \multirow[b]{3}{*}{ Aeromonas spp. } & \multicolumn{10}{|c|}{ Number of bacterial species isolated according to the type of sample (\%) } \\
\hline & \multicolumn{2}{|c|}{$\begin{array}{l}\text { Hospital } \\
\text { wastewater } \\
\mathbf{n}=10\end{array}$} & \multicolumn{2}{|c|}{$\begin{array}{l}\text { groundwater } \\
n=12\end{array}$} & \multicolumn{2}{|c|}{$\begin{array}{l}\text { DWSP } \\
n=120\end{array}$} & \multicolumn{2}{|c|}{$\begin{array}{l}\text { DWSS } \\
n=80\end{array}$} & \multicolumn{2}{|c|}{$\begin{array}{l}\text { Total } \\
n=222\end{array}$} \\
\hline & 06 & 24.00 & 11 & 33.33 & - & & - & & 17 & 06.42 \\
\hline Klebsiella pneumoniae & 07 & 28.00 & 06 & 18.18 & 35 & 26.72 & 10 & 13.16 & 58 & 21.89 \\
\hline Pseudomonas aeruginosa & - & & 06 & 18.18 & - & & 6 & 07.89 & 12 & 04.53 \\
\hline Escherichia coli & 06 & 24.00 & - & & 18 & 13.74 & 4 & 05.26 & 28 & 10.57 \\
\hline CNS & 06 & 24.00 & 10 & 30.30 & 60 & 45.80 & 24 & 31.58 & 100 & 37.74 \\
\hline Citrobacterspp & - & & - & & 06 & 04.58 & - & & 06 & 02.26 \\
\hline Enterobacterspp & - & & - & & 06 & 04.58 & 8 & 10.53 & 14 & 05.28 \\
\hline Proteus mirabilis & - & & - & & - & & 16 & 21.05 & 16 & 06.04 \\
\hline Serratia spp & - & & - & & - & & 8 & 10.53 & 08 & 03.02 \\
\hline Shigella spp & - & & - & & 06 & 04.58 & - & & 06 & 02.26 \\
\hline $\begin{array}{l}\text { Total number of bacterial } \\
\text { species isolated }\end{array}$ & 25 & & 33 & & 131 & & 76 & & 265 & \\
\hline
\end{tabular}


DWSP: Drinking Water in Sachets - Producer; DWSS: Drinking Water in Sachets - Street Seller; CNS: Coagulase Negative Staphylococcus; $\mathrm{n}$ : number of samples

Table 4. Distribution of resistance profiles of Gram-negative bacilli associated with the resistance genes detected 


\begin{tabular}{|c|c|c|c|c|c|c|}
\hline $\begin{array}{l}\text { Bacilli Gram- } \\
\text { negative } \\
\text { strains } \\
\text { isolated }\end{array}$ & Resistance profile & GW & HWW & DWSP & DWSS & $\begin{array}{l}\text { Resistance } \\
\text { Genes }\end{array}$ \\
\hline \multirow[t]{4}{*}{$\begin{array}{l}\text { Klebsiella } \\
\text { pneumoniae }\end{array}$} & $A M X^{R} A M P^{R} A M C^{R} C R O^{R} I M P^{S} A K^{S} N A^{S} G E N^{S}$ & 2 & 1 & 12 & 6 & $\begin{array}{l}\text { SUL1, } \\
\text { SUL2, } \\
\text { AADA, } \\
\text { SHV, }\end{array}$ \\
\hline & $A M X^{R} A M P^{R} A M C^{R} C R O^{R} I M P^{R} A K^{S} N A^{S} G E N^{S}$ & 2 & 1 & 13 & 0 & $\begin{array}{l}\text { SUL2, } \\
\text { AADA, } \\
\text { SHV, VIM }\end{array}$ \\
\hline & $A M X^{R} A M P^{R} A M C^{R} C R O^{S} I M P^{S} A K^{S} N A^{S} G E N^{S}$ & 2 & 3 & 6 & 4 & $\begin{array}{l}\text { SUL1, } \\
\text { SUL2, } \\
\text { AADA, }\end{array}$ \\
\hline & $A M X^{R} A M P^{R} A M C^{S} C R O^{S} I M P^{S} A K^{S} N A^{S} G E N^{S}$ & 0 & 2 & 4 & 0 & SUL2 \\
\hline \multirow[t]{3}{*}{$\begin{array}{l}\text { Escherichia } \\
\text { coli }\end{array}$} & $A M X^{R} A M P^{R} A M C^{R} C R O^{R} I M P^{S} A K^{S} N A^{S} G E N^{S}$ & 0 & 4 & 9 & 2 & $\begin{array}{l}\text { CTX-M 15, } \\
\text { TEM }\end{array}$ \\
\hline & $A M X^{R} A M P^{R} A M C^{R} C R O^{R} I M P^{S} A K^{S} N A^{R} G E N^{R}$ & 0 & 2 & 8 & 2 & SHV \\
\hline & $A M X^{R} A M P^{R} A M C^{S} C R O^{S} I M P^{S} A K^{S} N A^{S} G E N^{S}$ & 0 & 0 & 1 & 0 & - \\
\hline \multirow[t]{5}{*}{$\begin{array}{l}\text { Aeromonas } \\
\text { spp. }\end{array}$} & $A M X^{R} A M P^{R} A M C^{R} C R O^{R} I M P^{R} A K^{S} N A^{R} G E N^{S}$ & 0 & 3 & 0 & 0 & $\begin{array}{l}\text { SHV, VIM, } \\
\text { AADA, } \\
\text { SUL2 }\end{array}$ \\
\hline & $A M X^{R} A M P^{R} A M C^{R} C R O^{S} I M P^{S} A K^{R} N A^{R} G E N^{R}$ & 0 & 3 & 0 & 0 & - \\
\hline & $A M X^{R} A M P^{R} A M C^{R} C R O^{R} I M P^{R} A K^{S} N A^{S} G E N^{S}$ & 1 & 0 & 0 & 0 & $\begin{array}{l}\text { SHV, VIM, } \\
\text { AADA, } \\
\text { SUL2 }\end{array}$ \\
\hline & $A M X^{R} A M P^{R} A M C^{R} C R O^{R} I M P^{S} A K^{S} N A^{S} G E N^{S}$ & 5 & 0 & 0 & 0 & $\begin{array}{l}\text { SHV, } \\
\text { AADA, } \\
\text { SUL2 }\end{array}$ \\
\hline & $A M X^{R} A M P^{R} A M C^{R} C R O^{R} I M P^{S} A K^{S} N A^{S} G E N^{S}$ & 5 & 0 & 0 & 0 & $\begin{array}{l}\text { SHV, } \\
\text { AADA, } \\
\text { SUL2 }\end{array}$ \\
\hline \multirow[t]{3}{*}{$\begin{array}{l}\text { Pseudomonas } \\
\text { aeruginosa }\end{array}$} & $A M X^{R} A M P^{R} A M C^{R} C R O^{R} I M P^{S} A K^{S} N A^{R} G E N^{S}$ & 2 & 0 & 0 & 3 & $\begin{array}{l}\text { TEM, SHV, } \\
\text { SUL2 }\end{array}$ \\
\hline & $A M X^{R} A M P^{R} A M C^{R} C R O^{R} I M P^{S} A K^{S} N A^{S} G E N^{S}$ & 2 & 0 & 0 & 0 & SHV \\
\hline & $A M X^{R} A M P^{R} A M C^{R} C R O^{S} I M P^{S} A K^{S} N A^{S} G E N^{S}$ & 2 & 0 & 0 & 3 & $\begin{array}{l}\text { SUL1, } \\
\text { SUL2, } \\
\text { AADA, } \\
\text { SHV, }\end{array}$ \\
\hline \multirow[t]{2}{*}{$\begin{array}{l}\text { Enterobacter } \\
\text { spp. }\end{array}$} & $A M X^{R} A M P^{R} A M C^{R} C R O^{R} I M P^{S} A K^{S} N A^{S} G E N^{R}$ & 0 & 0 & 6 & 0 & $\begin{array}{l}\text { SUL2, } \\
\text { AADA }\end{array}$ \\
\hline & $A M X^{R} A M P^{R} A M C^{R} C R O^{R} I M P^{S} A K^{S} N A^{S} G E N^{S}$ & 0 & 0 & 0 & 5 & $\begin{array}{l}\text { TEM, SHV, } \\
\text { SUL2, } \\
\text { AADA }\end{array}$ \\
\hline
\end{tabular}




\begin{tabular}{|c|c|c|c|c|c|c|}
\hline & $A M X^{R} A M P^{R} A M C^{S} C R O^{S} I M P^{S} A K^{S} N A^{S} G E N^{S}$ & 0 & 0 & 0 & 3 & SUL1 \\
\hline \multirow[t]{2}{*}{ Serratia spp. } & $A M X^{S} A_{M P P^{S}} A_{M C} C^{S} C R O^{S} I M P^{S}{ }^{S} K^{S} N A^{S} G E N^{S}$ & 0 & 0 & 0 & 5 & $\begin{array}{l}\text { SUL1, } \\
\text { SUL2, } \\
\text { AADA }\end{array}$ \\
\hline & $A M X^{R} A M P^{R} A M C^{R} C R O^{R} I M P^{S} A K^{S} N A^{S} G E N^{S}$ & 0 & 0 & 0 & 3 & TEM, SHV \\
\hline \multirow[t]{5}{*}{$\begin{array}{l}\text { Proteus } \\
\text { mirabilis }\end{array}$} & $A M X^{R} A M P^{R} A M C^{R} C R O^{R} I M P^{S} A K^{S} N A^{S} G E N^{S}$ & 0 & 0 & 0 & 5 & $\begin{array}{l}\text { TEM, SHV, } \\
\text { SUL1 }\end{array}$ \\
\hline & $A M X^{R} A M P^{R} A M C^{R} C R O^{R} I M P^{R} A K^{S} N A^{S} G E N^{S}$ & 0 & 0 & 0 & 2 & $\begin{array}{l}\text { SHV, SUL2, } \\
\text { CTXM15, } \\
\text { NDM }\end{array}$ \\
\hline & $A M X^{R} A M P^{R} A M C^{R} C R O^{R} I M P^{S} A K^{R} N A^{R} G E N^{R}$ & 0 & 0 & 0 & 2 & $\begin{array}{l}\text { SUL1, SHV, } \\
\text { CTXM15 }\end{array}$ \\
\hline & $A M X^{R} A M P^{R} A M C^{R} C R O^{S}{ }^{M} P^{S} A K^{S} N A^{S} G E N^{R}$ & 0 & 0 & 0 & 5 & - \\
\hline & $A M X^{R} A M P^{R} A M C^{R} C R O^{S} I M P^{S} A K^{R} N A^{S} G E N^{R}$ & 0 & 0 & 0 & 2 & - \\
\hline $\begin{array}{l}\text { Citrobacter } \\
\text { spp. }\end{array}$ & $A M X^{R} A M P^{R} A M C^{R} C R O^{S}{ }^{\prime} M P^{S} A K^{S} N A^{S} G E N^{S}$ & 0 & 0 & 6 & 0 & - \\
\hline Shigella spp. & $A M X^{R} A M P^{R} A M C^{R} C R O^{R} I M P^{R} A K^{S} N A^{R} G E N^{S}$ & 0 & 0 & 6 & 0 & $\begin{array}{l}\text { SUL2, VIM, } \\
\text { NDM }\end{array}$ \\
\hline
\end{tabular}

HWW : Hospital WasteWater; GW : Groundwaters ; DWSP : Drinking Water IN Sachets-Producer ; DWSS: Drinking Water in Sachets-Street Seller; AMX: Amoxicillin ; AMP: Ampicillin ; AMC: Amoxicillin + Clavulanic acid ; IMP: Imipenem ; CRO: Ceftriaxone ; NA: Nalidixic Acid; AK: Amikacin ; GEN: Gentamycin ; R: Resistant; S: sensitive

Table 5. Distribution of resistance profiles of CNS strains isolated associated with the resistance genes detected 


\begin{tabular}{|c|c|c|c|c|c|c|}
\hline $\begin{array}{l}\text { Cocci Gram- } \\
\text { positive } \\
\text { strains } \\
\text { isolated }\end{array}$ & Resistance profile & GW & HWW & DWSP & DWSS & $\begin{array}{l}\text { Resistance } \\
\text { Gene }\end{array}$ \\
\hline \multirow[t]{17}{*}{ CNS } & $A M X^{R} O X A^{R} F O X^{R} V A^{S} T O B^{S} G E N^{S} F O^{S} D A^{S} E^{S}$ & 4 & 0 & 5 & 2 & Mec A, \\
\hline & $A M X^{R} O X A^{R} F O X^{S} V A^{S} T_{O B}{ }^{S} G E N^{S} F O^{S} D A^{S} E^{S}$ & 2 & 0 & 0 & 2 & Mec A \\
\hline & $A M X^{R} O X A^{R} F O X^{R} V A^{R} T O B^{S} G E N^{S} F O^{S} D A^{R} E^{S}$ & 2 & 0 & 5 & 0 & $\begin{array}{l}\text { Mec A, } \\
\text { Van B }\end{array}$ \\
\hline & $A M X^{R} O X A^{R} F O X^{R} V A^{R} T O B^{S} G E N^{S} F O^{R} D A^{S} E^{S}$ & 2 & 0 & 2 & 0 & Mec A \\
\hline & $A M X^{R} O X A^{R} F O X^{R} V A^{R} T O B^{R} G E N^{R} F O^{S} D A^{R} E^{S}$ & 0 & 6 & 5 & 0 & $\begin{array}{l}\operatorname{Mec} A \\
\operatorname{Van} A\end{array}$ \\
\hline & $A M X^{R} O X A^{R} F O X^{R} V A^{R} T O B^{S} G E N^{S} F O^{R} D A^{R} E^{S}$ & 0 & 0 & 10 & 0 & Mec A \\
\hline & $A M X^{R} O X A^{R} F O X^{S} V A^{S} T O B^{R} G E N^{S} F O^{S} D A^{S} E^{R}$ & 0 & 0 & 5 & 0 & - \\
\hline & $A M X^{S} O X A^{S} F O X^{S} V A^{S} T_{O B}{ }^{S} G E N^{S} F O^{S} D A^{S} E^{S}$ & 0 & 0 & 10 & 4 & - \\
\hline & $A M X^{R} O X A^{R} F O X^{R} V A^{S} T O B^{R} G E N^{R} F O^{R} D A^{S} E^{S}$ & 0 & 0 & 5 & 2 & $\operatorname{Mec} A$ \\
\hline & $A M X^{R} O X A^{R} F O X^{R} V A^{R} T O B^{S} G E N^{S} F O^{S} D A^{S} E^{S}$ & 0 & 0 & 5 & 2 & $\begin{array}{l}\text { Mec A, } \\
\text { Van A }\end{array}$ \\
\hline & $A M X^{R} O X A^{R} F O X^{R} V A^{S} T O B^{R} G E N^{S} F O^{S} D A^{S} E^{S}$ & 0 & 0 & 5 & 0 & Mec A \\
\hline & $A M X^{R} O X A^{R} F O X^{R} V A^{S} T O B^{R} G E N^{R} F O^{R} D A^{S} E^{R}$ & 0 & 0 & 3 & 2 & Mec A \\
\hline & $A M X^{R} O X A^{S} F O X^{S} V A^{S} T_{O B}{ }^{R} G E N^{S} F O^{S} D A^{S} E^{S}$ & 0 & 0 & 0 & 2 & - \\
\hline & $A M X^{R} O X A^{R} F O X^{S} V A^{S} T O B^{R} G E N^{R} F O^{R} D A^{S} E^{S}$ & 0 & 0 & 0 & 2 & - \\
\hline & $A M X^{R} O X A^{R} F O X^{S} V A^{S} T O B^{S} G E N^{S} F O^{R} D A^{R} E^{S}$ & 0 & 0 & 0 & 2 & - \\
\hline & $A M X^{R} O X A^{R} F O X^{R} V A^{S} T O B^{R} G E N^{S} F O^{R} D A^{R} E^{S}$ & 0 & 0 & 0 & 2 & Mec A \\
\hline & $A M X^{S} O X A^{S} F O X^{S} V A^{S} T O B^{R} G E N^{R} F O^{R} D A^{S} E^{S}$ & 0 & 0 & 0 & 2 & - \\
\hline
\end{tabular}

CNS: coagulase negative staphylococcus; HWW : Hospital wastewater; GW : Groundwater ; DWSP : Drinking water in Sachets-Producer ; DWSS: Drinking Water in Sachets-Street Seller; AMX: Amoxicillin ; OXA: Oxacillin ; VA: Vancomycin ; FOX: Cefoxitin ; TOB: Tobramycin ; GEN: Gentamycin; FO: Fosfomycin ; DA: Clindamycin ; E: Erythromycin ; R: Resistant; S: sensitive

\section{Figures}




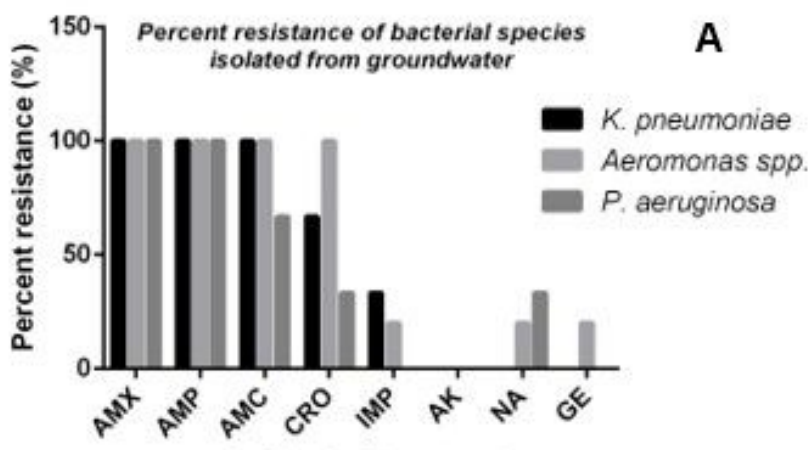

Antibiotic discs used

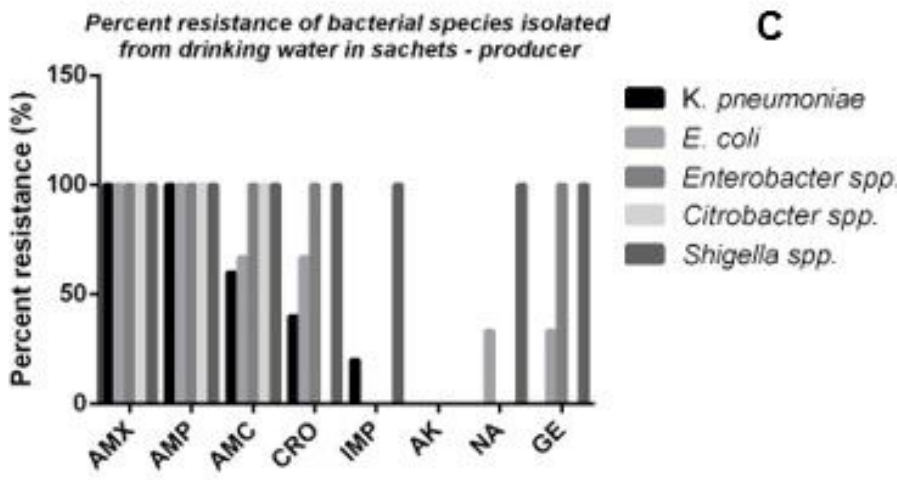

Antibiotic discs used

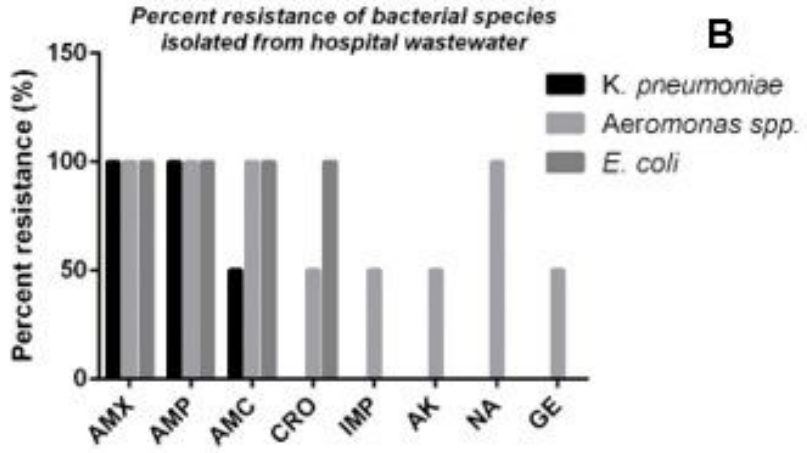

antibiotic discs used

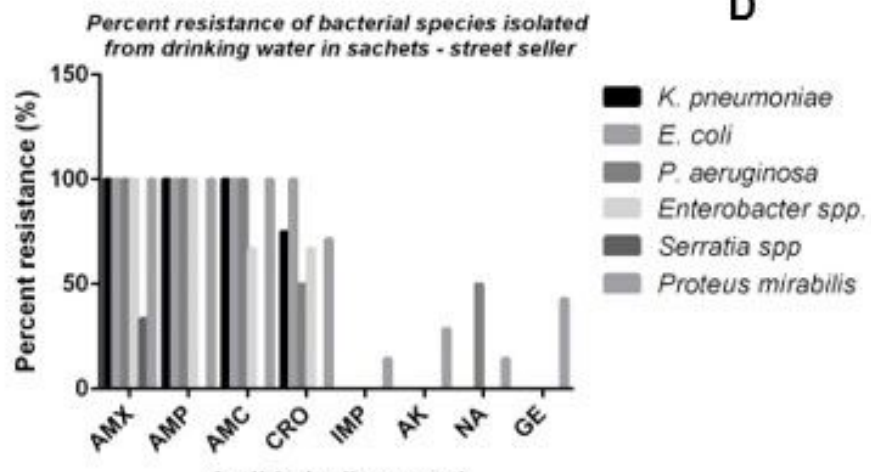

Antibiotic discs used

\section{Figure 1}

Resistance of Gram-negative bacilli strains to antibiotics used according to each type of sample (A: Percent resistance of bacterial species isolated from groundwater; B: Percent resistance of bacterial species isolated from hospital wastewater; C: Percent resistance of bacterial species isolated from drinking water in sachets producers; D: Percent resistance of bacterial species isolated from drinking water in sachets - producers) Legends of Figure 1: AMX: Amoxicillin; AMP: Ampicillin; AMC: Amoxicillin + Clavulanic acid; IMP: Imipenem; CRO: Ceftriaxone; NA: Nalidixic Acid; AK: Amikacin; GEN: Gentamycin 


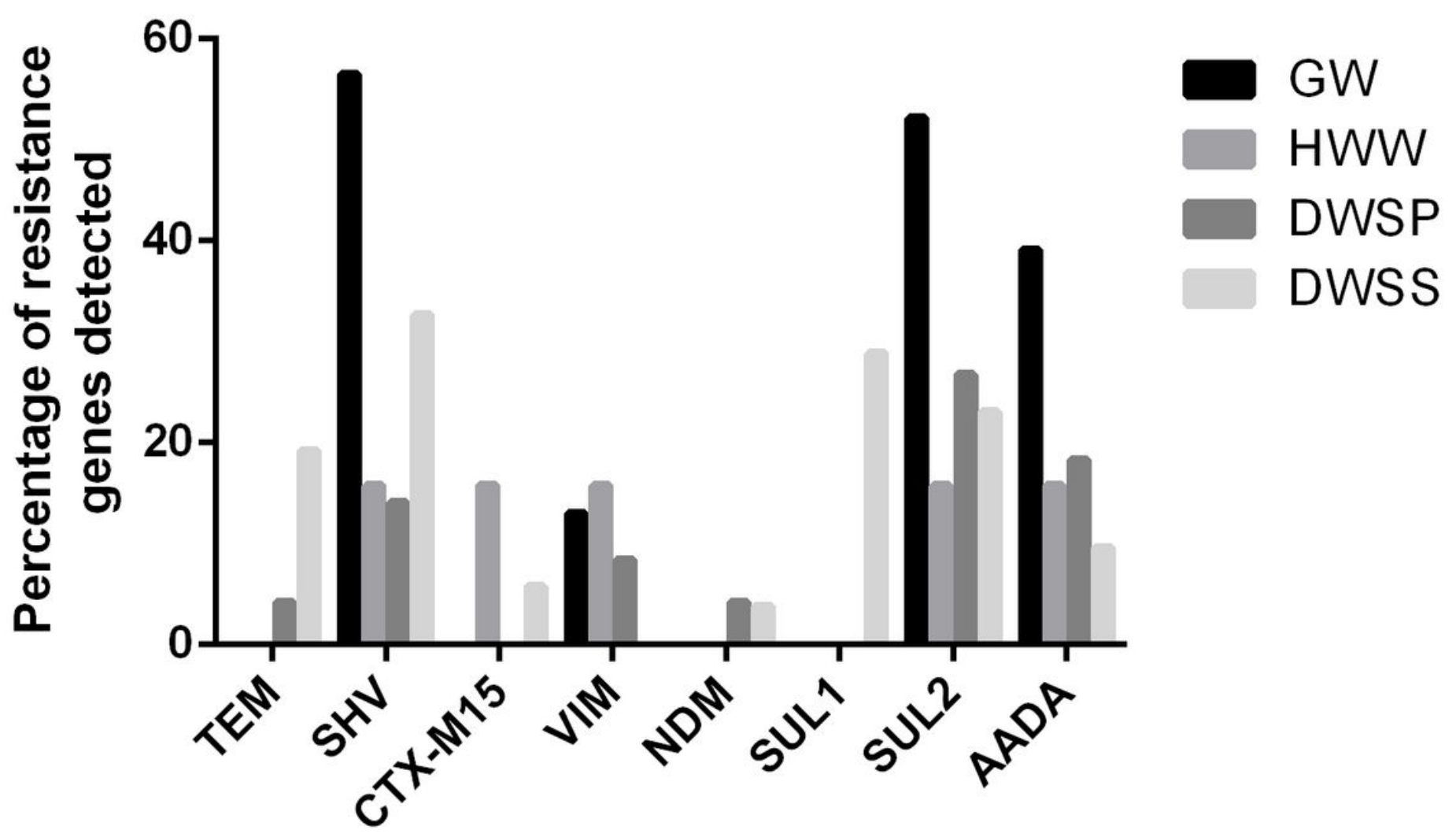

Resistance genes detected

Figure 2

Distribution of the resistance genes detected according to the strains of Gram-negative bacilli isolated from the different types of water samples Legends of figure 2: HWW: Hospital wastewater; GW: Groundwater; DWSP: Drinking water in Sachets-Producer; DWSS: Drinking water in Sachets-Street Seller 


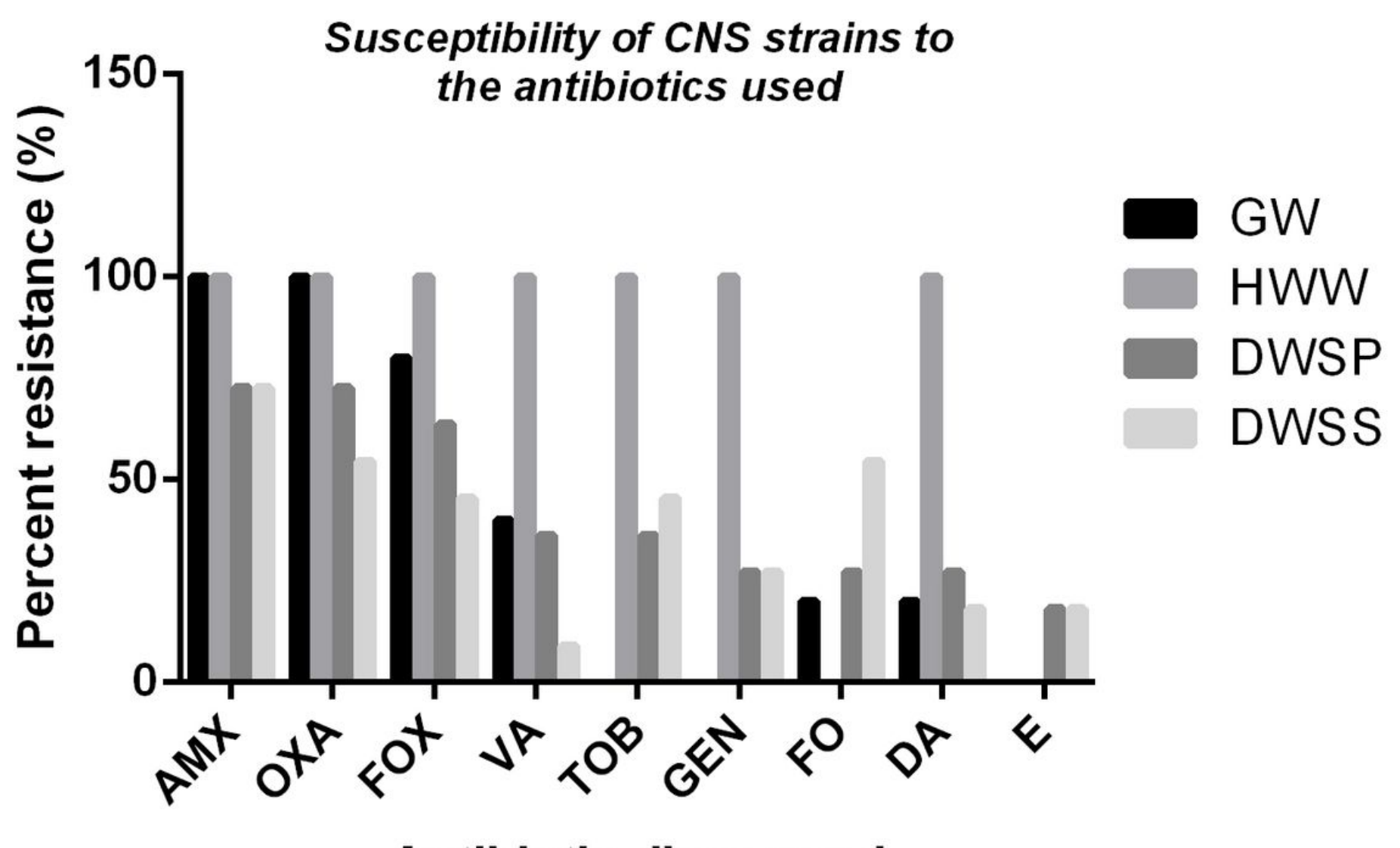

\section{Antibiotic discs used}

Figure 3

Resistance of CNS strains isolated from different types of water samples to the antibiotics tested Legends of figure 3: HWW: Hospital wastewater; GW: Groundwater; DWSP: Drinking water in Sachets-Producer; DWSS: Drinking water in Sachets-Street Seller; CNS: coagulase negative staphylococcus 


\section{Detection of resistance genes in CNS strains}

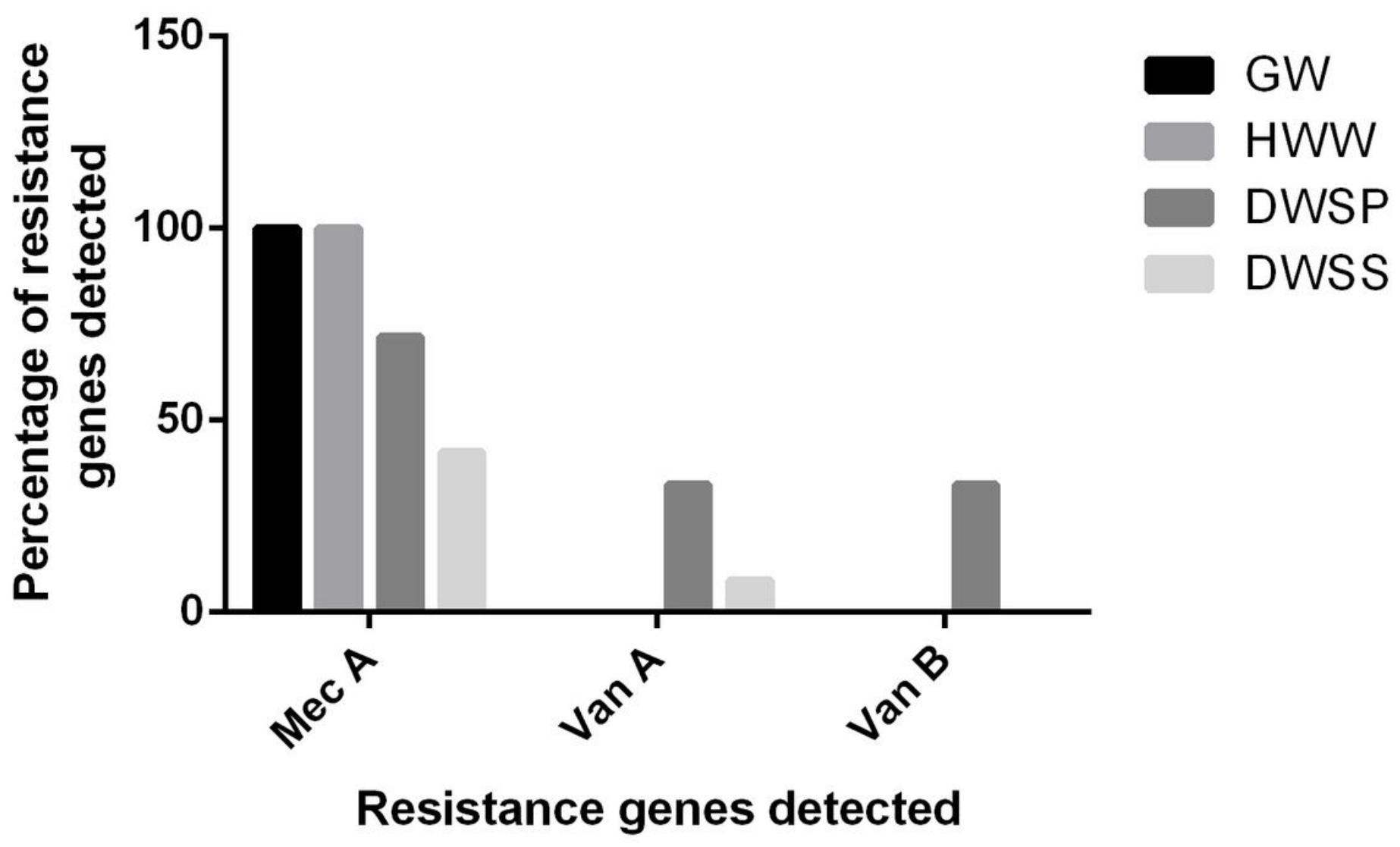

Figure 4

Distribution of the resistance genes detected according to CNS strains isolated from the different types of water samples Legends of figure 4: HWW: Hospital wastewater; GW: Groundwater; DWSP: Drinking water in SachetsProducer; DWSS: Drinking water in Sachets-Street Seller; CNS: coagulase negative staphylococcus 